\title{
SPECIAL PAPER \\ Mental health problems: journey from Baghdad to Europe
}

\author{
Yasir Abbasi ${ }^{1}$ MRCPsych and Adel Omrani ${ }^{2}$ MD BA
}

'Leeds Addiction Unit, Leeds, UK, email yabbasi@nhs.net

${ }^{2}$ Tunisian Bipolar Forum, Tunis, Tunisia, email omrani.adel@ gnet.tn

We thank Professor Peter E. Pormann MA DPhil, Professor of Classics and Graeco-Arabic of Classics and Graeco-A
Studies, School of Arts, Languages and Cultures, University of Manchester, for his help in providing access ro valuable literature and for to valuable literature and for reading an earlier draft of this article.
This article looks at the evidence that not only did mental health problems affect people in the past, but that the physicians of past eras made numerous attempts to understand, classify and treat mental illness. Our aim is to show the strong scientific reasoning during the medieval era, in the Islamic world in particular, and how the complexities encountered by physicians centuries ago still haunt psychiatrists today.

Leave aside what confuses common idiots, namely [the idea] that one can hit on [the right treatment] by experience [tajriba] without any reference to [scientific] knowledge $[\mathrm{ilm}]$. For such a thing does not exist, even if one were the oldest person, because the benefit which one derives from an appropriate treatment [in such a case] is merely the result of good luck. (Abu Bakr al-Razi [died circa 925], Muslim physician and philosopher, on evidencebased practice; see Akhlaq al-tabib, 1977, pp. 77-78)

Although some Muslim scholars have been recognised in the West for their contributions to science, many have been forgotten. Others are remembered by their Greek names. It has been claimed that descriptions of schizophrenia-like disorders were uncommon before the beginning of the 19th century in the Western world. But there are numerous cases of various mental health problems reported during the medieval Islamic era and they highlight the difficulty physicians faced in managing these conditions.

Islamic culture flourished during the medieval period (from the 7 th to the 15 th century). Under the aegis of the Muslim emperors, not only Muslim, but also Christian, Jewish and other scientists prospered, whether or not they were Arab. They drew on ancient Greek physicians such as Hippocrates, Rufus of Ephesus and Galen (Morgan, 2007, pp. xvi-xvii). And their work had a profound effect on European medicine, as works by Johannitius (Hunain ibn 'Ishaq), Avicenna (Ibn Sina) and Averroes (Ibn Rushd) were translated into Latin and became the core curriculum in the nascent universities of Europe. In this way, a constant interchange of ideas took place between the different shores of the Mediterranean (Pormann, 2008a, pp. 179196). The knowledge of previous civilisations was thus not just transmitted to another culture, but constituted the basis for innovation and change.

\section{The creation of dedicated hospitals and medical schools}

In the medieval Arab world, hospitals were generally called bimaristan. The word is of Persian origin, bimar meaning 'illness' or 'disease' and stan 'location' or 'place'. They not only cared for people who were ill but also became important centres for medical instruction, asylums for people with a mental illness (preceding Europe by over 500 years), retirement homes (meeting the basic maintenance needs of elderly and infirm people who lacked family support) and institutes for medical research (Pormann \& Savage-Smith, 2006, pp. 100-101).

When the new Abbasi dynasty ousted the previous Umayyad dynasty in the 750s AD, the capital moved from Damascus to Baghdad. Professor Peter Pormann (2008b) writes:

This city witnessed the foundation of the first hospital in the modern sense, that is to say institutions which were secular in orientation and open to a wide public irrespective of their creed; in which both poor and powerfu sought treatment; and where elite physicians not only looked after the patients, but also carried out research and trained the next generation of practitioners. These hospitals also developed important facilities for treating the mentally infirm.

Michael Dols (1992), in his book Majnun: The Madman in Medieval Islamic Society, discusses how hospitals became central institutions in the provision of mental healthcare in medieval Baghdad.

\section{Affective disorders \\ Depression and melancholy}

There is no evidence that the mindset of medieval Islamic physicians was comparable to our modern nosology. The concept of melancholy was greatly influenced by the works of Rufus, who theorised in terms of vapours, humoral imbalance and excess of black bile.

Ishaq Ibn Imran (died AD 903) explains that in the case of hypochondriac melancholy (Pormann 2008a, citing Garbers, 1977, p. 19), vapours rise from the stomach into the brain, where they damage the cognitive faculties. Sourcing his hypothesis on ideas by Galen, Ibn Imran divides melancholy in the hypochondriac and brain variety. The latter is further subdivided into four varieties, which broadly reflects how we currently categorise mental disorders: brain fever (organic causes, e.g. encephalitis); stupidity (intellectual disability); animal rage (manic or psychotic episode); and intense mood swings (bipolar-type illness).

The Jewish physician Ibn Maimun (Maimonides, died AD 1204) treated the Egyptian Sultan al-Afdal (son of Saladdin), who suffered from melancholy (Malinkhuliya). He gives an account in his 'medical swansong', where he describes the following symptoms of the sultan: 'he also mentions the occasional occurrence of melancholy, evil thoughts, desire for solitude and foreboding of death' (Pormann, 2008a). Hence Ibn Maimun possibly describes low mood, negative cognitions, 
demotivation and reclusiveness, followed by suicidal ideation.

Ibn Miskawaih (died AD 1030), a neo-platonic philosopher, when critically appraising Rufus's statement that 'those who devote too much thinking about a certain science end up suffering from melancholy', concluded that not all acts of thinking, especially not the kind of thought which results in the knowledge of the forms (Pormann, 2008a), are bad. Only engaging excessively in mental activities leads to melancholy.

\section{Elated mood or mania}

Ibn Sina states in one of his letters:

By this [cure], I have already treated people of the same station as Kings who suffered from difficult melancholy which turns into elation that is a lion-like madness [gunun sab'i]. (Pormann, 2008a, citing a translation by Bar-Sela et al, 1964, p. 36)

Al-Razi, in a chapter entitled 'On melancholy and other kinds of maddness' of his Book of Experiences (Kitab al-Tajarib), describes two interesting case studies (Pormann, 2008a), one of a young man who 'plucked his beard and showed his anger by tearing out clay from the wall', and another of a woman who spoke in a confused way, laughed excessively and had a red face.

He also differentiated between melancholia and madness (junun, possibly psychosis), where the sufferer of the latter experienced loss of reason and the former did not.

\section{Psychosis}

Physicians have described psychosis-like illness in their essays and case histories. Ishaq Ibn Imran, in his Essay on Melancholy (Maqala fi l-Malikhuliya), describes a patient with low mood and symptoms such as foolish acts, fear, delusions (waswas) and hallucinations (Youssef \& Youssef, 1996).

The most celebrated medieval medical encyclopaedia written by a physician is Ibn Sina's Canon of Medicine (al-Qanun fi l-tibb). He defined junun (madness) as an illness where reality is replaced by fantasy; he thought that the origin of such illnesses was from the middle part of the brain (Youssef \& Youssef, 1996).

Al-Masudi (died AD 956) described the condition of a king, Al-Mutadid, who experienced sudden onset of ideas of being persecuted and visual images with emotional turmoil.

\section{Sexual health}

Abu Bakr al-Razi wrote extensively about sex (Pormann, 2008a) in his treatise On Sexual Intercourse, Its Harmful and Beneficial Effects, and Treatment. In it, he suggested that too much sex weakens the eyesight, wrecks and exhausts the body, and speeds up ageing and senility. But he also reaffirmed Galen's view that when young men who have a lot of sperm do not have intercourse, they can have a heavy head, feel sad and lose their appetite and joy. There is a possibility that they were describing things the other way round and the loss of libido was actually due to low mood.
Al-Razi also describes people who abandoned sexual activity because of constant tension of the penis accompanied by pain and spasm.

A Christian author of Greek origin, Qusta Ibn Luqa (died AD 912) said that women also suffered from not having sex (Pormann, 2009) and described them as being afflicted by the 'suffocation of the womb' (ikhtinaq al-rahim) and apnoea (butlan al-nafas). It seems to be the equivalent of what the Greeks called 'hysteria', a term which also has its origins in the word for 'womb' (in Greek, hystera meant the uterus).

\section{Psychology, psychotherapy and other therapies}

Al-Razi was the first ever to postulate the existence of a form of melancholy that does not involve any humoral alteration. Such sine materia psychogenic melancholy should not be treated medically but rather receive psychological treatment.

Abu Zayd Al-Balkhi (died AD 934) asserted that the mind and body are interconnected (ishtibak) and that an imbalance of body and soul can affect the person in different ways (Haque, 2004).

Al-Tabari (died AD 870), in his ground breaking book The Paradise of Wisdom (Firdaws al-Hikma), explained that certain patients suffering from melancholia might benefit from talking to a witty physician who could build good rapport and trust (Haque, 2004).

Ibn Maimun also advocated 'psychic' remedies, such as listening to music, because they can provide calm and rest from anxieties and worries (Pormann, 2008b).

\section{Conclusion}

We need to revisit the origins of psychiatry and rediscover its history, so that we are able to comprehend it better and give due credit to all scientists, physicians, philosophers and thinkers lost in history.

\section{References}

Akhlaq al-tabib (1977) The Ethics of the Physician, translating AlRazi's Risāla ilā ba'd talāmidhatihì (Letter to a student). Cairo.

Dols, M. W. (1992) Majnun: The Madman in Medieval Islamic Society. Clarendon Press.

Haque, A. (2004) Psychology from Islamic perspective: contributions of early Muslim scholars and challenges to contemporary Muslim psychologists. Journal of Religion and Health, 43, 357-377.

Morgan, M. H. (2007) Lost History: The Enduring Legacy of Muslim Scientists, Thinkers and Artists (Tareekh Zae). National Geographic Society.

Pormann, P. E. (2008a) Rufus of Ephesus: On Melancholy. Mohr Siebeck.

Pormann, P. E. (2008b) Medical methodology and hospital practice: the case of tenth-century Baghdad. In The Age of al-Farabi: Arabic Philosophy in the 4th-10th Century (ed. P. Adamson), pp. 95-118. Warburg Institute. Reprinted in P. E. Pormann (ed.) (2011) Islamic Medical and Scientific Tradition, Critical Concepts in Islamic Studies, 4 vols, vol. 2, pp. 179-206. Routledge.

Pormann, P. E. (2009) Female patients and practitioners in medieval Islam: perspective. Lancet, 373, 1598-1599.

Pormann, P. E. \& Savage-Smith, E. (2006) Medieval Islamic Medicine. Edinburgh University Press.

Youssef, H. A. \& Youssef, F. A. (1996) Evidence for the existence of schizophrenia in medieval Islamic society. History of Psychiatry, 7 , $55-62$. 